\title{
O Mínimo Existencial, a Reserva do Possível e a correta aplicação da regra da proporcionalidade como limites jurídicos eficazes à autocontenção do poder judiciário na efetivação de Políticas Públicas
}

\author{
The Existential Minimum, the Possible Reserve and the correct \\ application of the proportionality rule as effective legal limits to the \\ self-containment of the judiciary in the effectiveness of public \\ policies
}

Luiz Henrique Urquhart Cademartori ${ }^{1}$ Gustavo Neroni Fernandes ${ }^{2}$

Resumo: o presente artigo tem como objetivo perscrutar os problemas jurídicos e políticos em torno da efetivação de políticas públicas pelo Poder Judiciário.Com esse intuito, vale-se do método predominantemente bibliográfico para passar em revista conceitos clássicos do Constitucionalismo e da Teoria do Estado, perpassando por fenômenos contemporâneos como o neoconstitucionalismo, a judicialização da política e o ativismo judicial para, enfim, constatar que a saída mais eficaz para restabelecer o equilíbrio entre os poderes é a autocontenção do Judiciário, por meio da adoção de mecanismos jurídicos criteriosos como o Mínimo Existencial, a Reserva do Possível e a correta aplicação da Regrada Proporcionalidade, quando tendente à concretização de políticas públicas.

Palavras-chave: Políticas Públicas; Judicialização da Política; Mínimo Existencial; Reserva do Possível; Regra da Proporcionalidade.

Abstract: This article aims to examine the legal and political problems surrounding the implementation of public policies by the Judiciary. With this intention, it uses the predominantly bibliographic method to review classic concepts of constitutionalism and state theory, through the use of contemporary phenomena such as neoconstitutionalism, judicialization of public policies and judicial activism, it is a more effective process to

${ }^{1}$ Graduado em Direito pela Universidade Federal de Santa Maria (1989), mestre em Direito pela Universidade Federal de Santa Catarina (1993), doutor em Direito pela Universidade Federal de Santa Catarina (2000) e pósdoutor pela Universidade de Granada - Espanha (2006). Professor permanente do Programa de Pós-Graduação em Direito da Universidade Federal de Santa Catarina.

${ }^{2}$ Graduado em Direito pela Universidade Estadual de Maringá - UEM e Pós-graduado em Direito do Estado com ênfase em Direito Constitucional pela Universidade Estadual de Londrina - UEL. 
reestablish a balance between the powers the self-containment of the judiciary, through the administration of juridical mechanisms such as the Existential Minimum, the Possible Reserve and the correct application of the Proportionality Rule, when tending to the concretization of public policies.

Keywords: Public Policies; Judicialization of Politics; Minimum Existential; Possible Reserve; Proportionality Rule.

\section{INTRODUÇÃO}

Em tempos de colapso financeiro nas contas do erário, releva-se demasiado importante a discussão acerca da judicialização da política. Em razão desse fenômeno, vez por outra o Judiciário adentra ao orçamento, direta ou indiretamente, ditando gastos não planejados pela Administração Pública, o que é problemático.

Conforme se delineará, a implementação de políticas públicas pelo Poder Judiciário apresenta-se mais como uma contingência do que uma invasão deliberada de uma função do Estado em outra. Não se pode desconsiderar que, concretamente, existe uma carência enorme na sociedade brasileira pela efetivação dos Direitos Fundamentais, mormente os Sociais, constitucionalizados na Carta Política de 1988 e desde então nunca levados a cabo de maneira satisfatória. Mencionada carestia decorre principalmente da inação dos Poderes Governamentais - Executivo e Legislativo - vácuo este que tem sido cada vez mais ocupado pelo Judiciário. Por outro lado, a experiência demonstra que esse movimento tem desfigurado o sistema, ocasionando choques entre os poderes, seja de ordem ideológica ou financeira.

Tendo isso em consideração, o presente estudo pretende passar em revista a Teoria Clássica de alguns conceitos como a Democracia, o Estado Social, a Aplicabilidade das Normas Constitucionais, a Constituição Dirigente e a Separação dos Poderes. Ato contínuo, acrescentar à análise os movimentos contemporâneos que impulsionam a questão posta, que são o Neoconstitucionalismo, a Judicialização da Política e o Ativismo Judicial para, enfim, formular um procedimento criterioso a se submeter a decisão, que passa pelo Mínimo Existencial, a Reserva do Possível e a correta aplicação da Regra da Proporcionalidade, com vistas a reequilibrar a relação dos Poderes pela autocontenção do Judiciário na efetivação de políticas públicas. 


\section{DEMOCRACIA, ESTADO SOCIAL, APLICABILIDADAE DAS NORMAS CONSTITUCIONAIS, CONSTITUIÇÃO DIRIGENTE E SEPARAÇÃO DOS PODERES}

Revela-se da mais alta envergadura nos Estados contemporâneos a compreensão do Princípio Democrático. Com esse escopo, nada seria mais clássico do que falar dos gregos ${ }^{3}$. Mas como este não é o tema central do presente estudo, convém passar para algo mais próximo do constitucionalismo ${ }^{4}$.A fim de ilustrar a democracia na América, ninguém melhor do que Alexis de Tocqueville. Indagando-se como seria possível dizer, rigorosamente, que nos Estados Unidos é o povo que governa, o filósofo liberal aduz que, na América, no fim das contas é o povo que nomeia aquele que faz a lei, a executa e ele próprio constitui o Júri que pune as infrações às normas. Embora revista-se da forma representativa, os valores sociais não poderiam, segundo este modelo, encontrar obstáculos duradouros que os impedissem de dirigir a sociedade. ${ }^{5}$

Eis que é possível promover, assim, um encontro entre democracia e liberalismo, de maneira a entender que aquela é um estágio de desenvolvimento deste. Em que pese a crítica necessária sobre a noção de igualdade meramente jurídica, a fórmula política do Estado Liberal é a soberania popular, materializada pelo sufrágio universal. Observa Norberto Bobbio que a maior garantia dos direitos de liberdade é que os cidadãos

\footnotetext{
3“O pensamento político grego transmitiu uma célebre tipologia das formas de governo dos muitos, dos mais, da maioria, ou dos pobres (mas onde os pobres tomam a dianteira é sinal de que o poder pertence ao pléthos, à massa), em suma, segundo a própria composição da palavra, como governo do povo, em contraposição ao governo de uns poucos. Seja o que for que se diga, a verdade é que não obstante o transcorrer dos séculos e todas as discussões que se travaram em torno da diversidade da democracia dos antigos com respeito à democracia dos modernos, o significado descritivo geral do termo não se alterou, embora se altere, conforme os tempos e as doutrinas, o seu significado valorativo, segundo o qual o governo do povo pode ser preferível ao governo de um ou de poucos e vice-versa" (In BOBBIO, Norberto. Liberalismo e Democracia. Trad. Marco Aurélio Nogueira. São Paulo: Brasiliense, 2000, p. 31).

${ }^{4} \mathrm{O}$ Constitucionalismo pode ser entendido como uma ideologia liberal que propugna o governo das leis acima do governo dos homens. Significaria, em síntese, a criação de instituições através de lei formal para limitar e controlar o poder político e vincular o exercício desse poder a normas bilateralmente vinculantes para os detentores dos poderes políticos e para os cidadãos (V. CANOTILHO, José Joaquim Gomes. Direito Constitucional e Teoria da Constituição. $7^{\text {a }}$ ed. Coimbra: Almedina, 1993, p. 65).

5 TOQUEVILLE, Alexis. A Democracia na América: Leis e Costumes. Trad. Eduardo Brandão. São Paulo: Martins Fontes, 2005, p. 197. De saída já salta aos olhos que o controle social exercido pelos ianques sobre os juízes na época de Tocqueville está ausente no Brasil, onde os juízes são em sua maior parte concursados (artigo 93, I CF) ou escolhidos para os tribunais em um sistema corporativo (artigo 93, III CF) e a competência reservada ao Tribunal do Júri bastante reduzida (artigo 5, XXXVIII, "d" CF). Isto, contudo, não tem o condão de fazer com que os países que adotem esse modelo sejam menos democráticos do que outros. Trata-se de mera conformação de uma estrutura judiciária fundada em uma cultura jurídica diversa.
} 
tenham condições de defendê-los contra eventuais excessos. Assim, o melhor remédio contra o abuso do poder é a participação, direta ou indireta, dos cidadãos na formação das leis. ${ }^{6}$

A democracia não pode ser encerrada, todavia, no princípio majoritário e nas condições meramente formais, $i$. e., a forma e o método das decisões sem nada dizer respeito às substâncias e aos conteúdos em relação aos quais a nenhuma maioria é lícito decidir. Para Ferrajoli, a democracia que se define somente sob esses aspectos seria inadequada e incompleta. $\mathrm{O}$ jurista italiano defende, com razão, que a soberania popular deve ser entendida "[...] de um lado como o conjunto dos poderes e contrapoderes que são os direitos fundamentais, atribuídos a todos e a cada um, isto é a toda população, como outros tantos fragmentos de soberania; de outro e sobretudo, como uma garantia negativa contra o despotismo $[\ldots]^{\prime, 7}$.

Definir democracia não é tarefa fácil nem o que se pretende fazer aqui. Em vez de se perguntar o que é esse fenômeno, talvez fosse mais oportuna a indagação: por que a democracia? Aí sem dúvida apareceriam muitas respostas. ${ }^{8}$ A mais convincente é a célebre definição atribuída a Churchill, segundo o qual a democracia seria "o pior dos regimes com a exceção de todos os outros". Ela é, assim, repleta de falhas e suscetível a crises, oque pode ser medido é a sua qualidade ${ }^{9}$ ou a sua intensidade ${ }^{10}$.

Conquanto as críticas sobre o seu desempenho, a conjugação entre a democracia liberal e o constitucionalismo sobrepõe o governo das leis ${ }^{11}$ ao governo dos homens e impede, se os mecanismos funcionarem bem, que estes atentem contra a liberdade de seus pares ou os impeçam, por muito tempo,de,se insatisfeitos, reverberarem os valores

\footnotetext{
${ }^{6}$ V. BOBBIO, Norberto. Liberalismo e Democracia.Trad. Marco Aurélio Nogueira. São Paulo: Brasiliense, 2000, p. 42-44.

${ }^{7}$ FERRAJOLI, Luigi. Garantismo: Uma Discussão sobre Direito e Democracia. Trad. Alexander Araújo de Souza. Rio de Janeiro: Editora Lumen Juris, 2012, p. 80.

${ }^{8}$ Robert A. Dahl apresenta ao menos dez consequências desejáveis decorrentes da democracia: V. DAHL, Robert A. Sobre a Democracia.Trad. Beatriz Sidou. Brasília: Editora UNB, 2001, p. 58.

${ }^{9}$ V. v. g.O'DONNEL, Guilhermo. Democracia, Desenvolvimento Humano e Direitos Humanos. Revista Debates. Porto Alegre, v.7, n. 1, p. 94, jan.-abr. 2013.

${ }^{10}$ V. v. g. SANTOS, Boaventura de Sousa. Renovar a Teoria Crítica e Reinventar a Emancipação Social. São Paulo: Boitempo, 2007, p. 83-102.

11 "E o que é a democracia se não um conjunto de regras (as chamadas regras do jogo) para a solução dos conflitos sem derramamento de sangue? E em que consiste o bom governo democrático se não, acima de tudo, no rigoroso respeito a estas regras?" (In BOBBIO, Norberto. O Futuro da Democracia: Uma Defesa das Regras do Jogo. $6^{\text {a }}$ ed.Trad. Marco Aurélio Nogueira. Rio de Janeiro: Paz e Terra, 1986, p. 169).
} 
majoritários da sociedade nas decisões políticas. Esse arquétipo propicia um ambiente favorável para que a luta política e as mudanças fluam, mas o alicerce permaneça.

Uma ideia construída dentro do jogo democrático, sobre os valores fundantes da liberdade e dos direitos individuais e políticos é o próprio Estado Social.O capitalismo liberal teria submetido o assalariado a um regime de divisão social do trabalho desumano. $\mathrm{O}$ despertar da consciência dessa opressão abriu espaço para um tratamento jurídico diferenciado dessas questões. Finalmente, com condições muito específicas, o período que se seguiu ao pós-guerra permitiu que se somassem aos velhos direitos individuais uma nova ordem de direitos fundamentais. ${ }^{12} \mathrm{Na}$ dicção de Bonavides: “[...] o Estado Social é, sob certo aspecto, decorrência do dirigismo que a tecnologia e o adiantamento das ideias de colaboração humana e social impuseram ao século [...]."13

Inspirado, dentre outros, por Rousseau, Hegel e Marx, guardadas as devidas diferenças teóricas e adaptações institucionais, o Estado Social busca superar a contradição entre a igualdade política (já conquistada sob a égide do Estado Liberal e do Constitucionalismo) e a desigualdade social. Não é, portanto, um Estado Socialista ou uma ideologia revolucionária. ${ }^{14}$ Tem por nota característica a interessante vantagem de apostar no aprofundamento da democracia como solução para os problemas sociais e no constitucionalismo a sua tônica, tanto o é que eleva à condição de norma constitucional os chamados direitos fundamentais de segunda dimensão. ${ }^{15}$

Sobre o Estado Liberal aduz Fábio Konder Comparato que neste modelo não competiria ao Estado guiar a sociedade para a realização de fins comuns, mas cingir-se, tão somente, a manter a ordem e a segurança, sob a égide de leis gerais, permitindo-se, assim, que

\footnotetext{
${ }^{12}$ V. PASSOS, J. J. Calmon de. O Futuro do Estado e do Direito do Estado. Democracia, Globalização eo Nacionalismo. Revista Eletrônica obre a Reforma do Estado (RERE). Salvador: Instituto de Direito Público da Bahia, n. 2, p. 11-12, jun.-ago. 2005.

${ }^{13}$ BONAVIDES, Paulo. Teoria Constitucional da Democracia Participativa. São Paulo: Malheiros, 2001, p. 145. O autor se refere ao século XX.

${ }^{14}$ V. BONAVIDES, Paulo. Do Estado Liberal ao Estado Social. 11ª ed. São Paulo: Malheiros, 2013, p. 182-204.

${ }^{15} \mathrm{Na}$ clássica compreensão de Bobbio, os direitos fundamentais são sempre uma conquista histórica, que acompanha as necessidades de seu tempo. Quando a evolução técnica ou o próprio exercício do poder dos homens sobre os homens se apresentam como uma ameaça, nascem os direitos fundamentais, a partir da exigência de que o mesmo poder intervenha de modo protetor. Nesse sentido, aqueles entendidos como os de primeira dimensão corresponderia aos direitos de liberdade, um não-agir do Estado e a segunda, os direitos sociais, requereriam uma ação positiva daquele (V. BOBBIO, Norberto. A Era dos Direitos. Trad. Carlos Nelson Coutinho. São Paulo: Elsevier, 2004, p. 9).
} 
cada cidadão realizasse, livremente, o seu interesse individual. Sob o novo paradigma, o jurista assenta que o Estado Social assumiria a função de ajudar a sociedade a encontrar o caminho para o bem comum, entendido este como o conjunto de metas e objetivos a serem alcançados através de políticas públicas. ${ }^{16}$ A partir dessa ideia, já é possível introduzir a ideia de Constituição Dirigente de Canotilho, mas não sem antes passar em revista a Teoria da Aplicabilidade das Normas Constitucionais.

Foi preciso gastar alguma tinta para superar a concepção de Constituição como mera vontade de poder ou mera expressão ontológicada sociedade (os fatores reais de poder Lassale) até que ela fosse encarada também como um dever-ser. A Constituição converte-se assim em força ativa pela condicionante de uma consciência geral de "Vontade de Constituição". Esta noção deve ser realçada constantemente pelo Direito Constitucional, a quem incumbe lembrar sempre aos agentes políticos de que de seu texto emanam normasvinculantes. ${ }^{17}$ Encarando o sistema jurídico como um ordenamento escalonado de camadas de normas, Hans Kelsen vai além e observa que as normas jurídicas regulam o procedimento pelo qual outrassão produzidas. Neste sentido, a Constituição estaria na camada jurídico-positiva mais alta e teria como função essencial regular os órgãos e o procedimento da produção jurídica em geral. Não ignora, todavia, que a Constituição poderia determinar também o conteúdo de leis futuras, prescrevendo ou excluindo determinados conteúdos. ${ }^{18}$

Concebido o escopo atribuído por Kelsen à Constituição (sentido jurídico: puro dever-ser), José Afonso da Silva sistematiza as normas constitucionais, quanto à sua aplicabilidade, em ao menos três grandes categorias. São, assim, de eficácia plena aquelas que, desde a entrada em vigor da Constituição, produzem ou têm a possibilidade de produzir os seus efeitos essenciais - são, portanto, de aplicabilidade imediata. As normas constitucionais de eficácia contida, por seu turno, são aquelas em que o constituinte regulou suficientemente os interesses relativos a determinada matéria, mas deixou margem à atuação restritiva por parte da competência discricionária do poder público - são assim também de

\footnotetext{
${ }^{16}$ COMPARATO, Fábio Konder. O Ministério Público na Defesa dos Direitos Econômicos, Sociais e Culturais. In GRAU, Eros Roberto; CUNHA, Sérgio Sérvulo da.Estudos de Direito Constitucional em Homenagem a José Afonso da Silva. São Paulo: Malheiros, 2003, p. 253.

${ }^{17}$ V. HESSE, Konrad. A Força Normativa da Constituição. Trad. Gilmar Ferreira Mendes. Porto Alegre: Sérgio Antônio Fabris Editor, 1991.

${ }^{18}$ V. KELSEN, Hans. Teoria Pura do Direito. $6^{\text {a }}$ ed. Trad. J. Cretella Jr. e Agnes Cretella. São Paulo: Revista dos Tribunais, 2009, p. 132-133.
} 
aplicabilidade imediata, embora possa ter a sua incidência restringida pelo legislador. Por fim, têm-se as normas de eficácia limitada naquelas de "princípio institutivo", através das quais o constituinte traça esquemas gerais de estruturação e atribuições para que o legislador os realize. Sendo elas impositivas ou facultativas, fato é que não possuem aplicabilidade concreta imediata, embora possam auxiliar na interpretação do conjunto do ordenamento. ${ }^{19}$ Nesta última categoria é que se localizam as chamadas "normas constitucionais programáticas", por meio das quais "[...] o constituinte, em vez de regular, direta e imediatamente, determinados interesses, limitou-se a traçar-lhes os princípios para serem cumpridos pelos seus órgãos [...], como programas das respectivas atividades, visando à realização dos fins sociais do Estado." ${ }^{20}$

Para Canotilho, a Lei Fundamental deveria se aproximar de um plano em que a realidade seria assumida como tarefa. A discricionariedade legislativa não opera no âmbito da Constituição Garantia (que trata dos direitos fundamentais, p. ex.). Não obstante, as normas diretivas comportam um grau de liberdade ao Parlamento. A vinculação do legislador à Constituição Dirigente, importante frisar, não é como a do ato administrativo à lei. Aqui não é cabível a ideia de discricionariedade como a escolha entre fins. A discricionariedade legislativa "[...] só pode consistir na complementação do fim subjacente à norma garantidora de um espaço discricionário" 21 e essa observação faz toda a diferença.

Do exposto até aqui, ressai a necessidade de se construir um Estado Democrático e Social de Direito, desenhado em uma Constituição jurídica (normativa), poderosa o suficiente para barrar o arbítrio e levada a sério quanto à realização de suas diretivas. Para tanto, eis que dependerá da melhor interação possível entre os poderes que constitui- o que requer a compreensão do Princípio da Tripartição dos Poderes.

Montesquieu, cujas análises precedem as correntes do constitucionalismo, encontrou na atribuição das funcionalidades do poder a órgãos diversos uma maneira de limitá-lo, afinal, para ele, o poder é testado até os seus limites. Para que não se pudesse abusar

\footnotetext{
${ }^{19}$ V. SILVA. José Afonso da.Aplicabilidade das Normas Constitucionais. $7^{\mathrm{a}}$ ed. São Paulo: Malheiros, 2007, p. 88-166.

${ }^{20}$ Ibidem, p. 138.

${ }^{21}$ CANOTILHO, José Joaquim Gomes. Constituição Dirigente e Vinculação do Legislador: Contributo para a Compreensão das Normas Constitucionais Programáticas. Coimbra: Coimbra Editora, 2001, p. 236.
} 
do poder, era preciso que, pela disposição das coisas, o poder limitasse o poder ${ }^{22} \mathrm{E}$ radicaliza em relação ao judiciário, que para ele seria, de algum modo, nulo: “[...] os juízes de uma nação não são, como dissemos, mais que a boca que pronuncia as sentenças da lei, seres inanimados que não podem moderar nem sua força nem seu vigor" ${ }^{\text {,23. }}$

A divisão dos poderes fundamenta-se, pois, em dois elementos: a especialização funcional e a independência orgânica. Forçoso reconhecer, no entanto, que o princípio não pode ser encarado com a rigidez que possuía para os filósofos liberais franceses da época pré-revolucionária, haja vista que, como desenvolvido alhures, a sucessão de acontecimentos e a consecução de um Estado mais presente na vida das pessoas ampliaram sobremaneira as frentes de sua atuação. Requer-se que os poderes sejam independentes e harmônicos entre si (artigo $2 \mathrm{CF}$ ), mas isso não significa que sejam estanques. Pelo contrário, as interferências de um poder em outro estão presentes estabelecendo um sistema de freios e contrapesos. ${ }^{24}$

Insta registrar que, ao contrário do que diz Montesquieu, o poder judiciário não é nulo. Incumbe-lhe a função de dizer o direito (jurisdição) e existe aí a manifestação de um poder. O que ocorre, fruto do que temia o barão Charles Louis de Secondat, é que a atividade cognitiva de se aplicar (interpretar) ${ }^{25}$ a lei possa ser convertida num ato de vontade do agente e, por isso, num abuso. Na contemporaneidade, este é um fenômeno muito em voga. Ferrajoli adverte sobre o uso inflacionado da categoria de "conflito entre direitos", como subterfúgio a ensejar uma perniciosa discricionariedade judicial. Quando constatados efetivamente esses conflitos, o que para alguns são chamados de "casos difíceis", o autor italiano não pretende calar o juiz, como gostaria Montesquieu, e reconhece que ao Judiciário continua a incumbir a função de revelar o significado e o alcance das normas. Esta é uma situação de direito e não afeta à autodeterminação política do povo, que poderia se revelar casuística neste caso - a separação de poderes é assim um valor garantista. O que não se pode é cair na armadilha de confundir as funções, pois, na dicção de Montesquieu "tudo estaria perdido se o poder

${ }^{22}$ MONTESQUIEU, Charles Louis de. O Espírito das Leis. Trad. Cristina Muraschco. São Paulo: Martins Fontes, 1993, p. 74.

${ }^{23}$ Ibidem, p. 151-152.

${ }^{24}$ V. SILVA. José Afonso da.Curso de Direito Constitucional Positivo. 25a ed. São Paulo: Malheiros, 2005, p. 109-110.

${ }^{25}$ Numa visão concretista, não se pode cindir as operações de interpretar e de aplicar a norma. Nesse sentido, V.ABBOUD, Georges. Jurisdição Constitucional e Direitos Fundamentais. São Paulo: Revista dos Tribunais, 2011 , p.78. 
judiciário estivesse unido ao legislativo" 26 . Sobre a separação e a independência da função jurisdicional das funções legislativas e de governo, Ferrajoli, de arremate, aduz que garantiria de fato à jurisdição o seu caráter tendencialmente cognitivo, por força do qual "[...] uma sentença é válida e justa não por ser querida ou compartilhada por uma maioria política, mas por ser fundada em uma correta verificação de seus pressupostos de fato e de direito". ${ }^{27}$

Cumpre indagar até onde uma justiça de base moral pode ser entendida como um pressuposto de direito para a decisão judicial, se é que pode, e por quais frestas ela tem adentrado no sistema, provocando, dentre outras coisas, as incursões indevidas do poder de julgar na seara própria dos demais, que são as políticas públicas. Nessa esteira, é preciso discorrer alguns parágrafos sobre o Neoconstitucionalismo, o que inaugura o capítulo a seguir.

\section{NEOCONSTITUCIONALISMO, JUDICIALIZAÇÃO DA POLÍTICA E ATIVISMO JUDICIAL}

O fenômeno do neoconstitucionalismo é dos mais heterogêneos. Não obstante, é possível identificar nas várias de suas manifestações alguns denominadores comuns. Daniel Sarmento aponta, p. ex., o reconhecimento da força normativa dos princípios, a constitucionalização do Direito e a judicialização da política e das relações sociais. Aduz ainda algumas outras características que, embora o autor repute como pontos em comum, provavelmente assim não mais o sejam como o recurso frequente a métodos abertos de interpretação e a reaproximação entre o Direito e a moral. ${ }^{28}$

Para Luis Pietro Sanchís, o neoconstitucionalismo deve ser entendido também como uma ideologia ${ }^{29}$, o que é inegável, bastando lembrar que o próprio constitucionalismo liberal igualmente o era. Aduz Alfonso Garcia Figueroa que o movimento em liça acabou por

\footnotetext{
${ }^{26}$ FERRAJOLI, Luigi. Garantismo: Uma Discussão sobre Direito e Democracia. Trad. Alexander Araújo de Souza. Rio de Janeiro: Editora Lumen Juris, 2012, p. 59-71.

${ }^{27}$ Ibidem, p. 70

28 V. SARMENTO, Daniel. O Neoconstitucionalismo no Brasil: Riscos e Possibilidades. In LEITE, George Salomão; SARLET, Ingo Wolfgang (Orgs.).Direitos Fundamentais e Estado Constitucional: Estudos em Homenagem a J.J. Gomes Canotilho. São Paulo: Editora Revista dos Tribunais, 2009, p. 9-10.

${ }^{29}$ V. SANCHÍS, Luis Prieto. Neoconstitucionalismo y Ponderación Judicial. In CARBONELL, Miguel (Org.). Neoconstitucionalismo(s). Madrid: Editorial Trotta, 2003, p. 123-158.
} 
conferir ao Direito uma forte carga axiológica que impõe ao pensamento positivista tradicional não abandonar a sua teoria descritiva do Direito, mas combiná-la com uma teoria normativa da argumentação jurídica que guiasse o operador jurídico na resolução de casos difíceis. ${ }^{30}$ Hart defendia as conexões entre Direito e moral como um "conteúdo mínimo do direito natural no direito positivo", a fim de que as pessoas tivessem alguma razão para submeterem-se às normas jurídicas. Essa infiltração da moral no Direito, antes encarada como exceção necessária, no neoconstitucionalismo toma contornos de regra para a solução dos problemas de convivência humana, cujo método é a profusão de conceitos jurídicos indeterminados ${ }^{31}$, exatamente o que ocorre com as diretivas constitucionais enunciadoras de políticas públicas.

Luigi Ferrajoli, ao contrário dos neoconstitucionalistas, sustenta a tese de uma recíproca autonomia entre o Direito e a moral, tentando fazer uma distinção bastante clara entre juízos jurídicos de validade e juízos ético-políticos de justiça. Assenta que o Direito não é em si um mal, ou intrinsecamente imoral, mas o poder que o exerce (extrajurídico), se desvestido de limites e vínculos a ele impostos pelo próprio Direito, apresentaria um grau irredutível de ilegitimidade. ${ }^{32}$

É possível perceber, portanto, que no tocante ao tema desta pesquisa, as teses neoconstitucionalistas podem ser a origem do problema e por onde passa a sua solução, eis que a tão bem quista constitucionalização do Direito impeliu o Poder Judiciário a adotar métodos mais abertos de interpretação a fim de obter maior efetividade dos direitos fundamentais positivados na Constituição e de outro lado esse movimento acabou por reduzir o grau de legitimidade de suas ações, inclusive concernentes às políticas públicas, antes tidas como assunto típico dos outros poderes. É indubitável que a abertura promovida pela ingerência da Moral na searado Direito desperta um papel acentuadamente criativo dos juízes, terminando por igualar, em alguns casos, a função jurisdicional à legislativa. ${ }^{33}$

\footnotetext{
30 V. FIGUEROA, Alfonso Garcia. La Teoria delDerecho em Tiempos de Constitucionalismo. In CARBONELL, Miguel (Org.). Neoconstitucionalismo(s). Madrid: Editorial Trotta, 2003, p. 159-186.

${ }^{31}$ V. CADEMARTORI, Luiz Henrique Urquhart; DUARTE, Francisco Carlos. Hermenêutica e Argumentação Neoconstitucional. São Paulo: Atlas, 2009, p. 44.

${ }^{32}$ V. FERRAJOLI, Luigi. Garantismo: Uma Discussão sobre Direito e Democracia. Trad. Alexander Araújo de Souza. Rio de Janeiro: Editora Lumen Juris, 2012, p. 20-24.

${ }_{33}$ CAPPELLETTI, Mauro. Juízes Legisladores?. Trad. Carlos Alberto Álvaro de Oliveira. Porto Alegre: Sérgio Antônio Fabris Editor, 1999, p. 73.
} 
É neste quadro que exsurge o ativismo judicial. Robert A. Dahl já preconizava desde há muito que uma decisão sobre políticas públicas consistiria em uma escolha eficaz entre alternativas sobre as quais há alguma incerteza e, nesse sentido, ninguém seria capaz de questionar que o Poder Judiciário devesse tomar decisões sobre estes assuntos. Porém, reconhece, esta proposição não seria muito útil para solucionar o problema, vez que“O fundamental é a medida na qual uma corte ou tribunal pode e toma decisões sobre políticas públicas desviando-se dos critérios 'jurídicos' encontrados na jurisprudência, nas leis e na constituição"34. Na mesma linha é o magistério de Canotilho, que, após constatar não valer a pena retornar aos modelos jacobinos de juízes, que se limitavam a executar ou declarar o Direito, mas nunca criá-lo, indaga-se se magistraturas ativas conduziriam a um Estado de juízes, ao que conclui não ser isto possível se forem recortados limites jurídicosconstitucionais, ou seja, limites de direito constitucional positivo, ao ativismo judicial ${ }^{35}$.

Eis, portanto, que o constitucionalismo liberal estava, dentre outros, calcado na democracia e na separação de poderes como suas vigas mestras, dada a experiência do seu passado recente de abuso do poder por minorias que o detinham. Superada essa fase, as teses neoconstitucionalistas baseiam-se na compreensão de que somente isso seria assaz insuficiente para a concretização dos direitos fundamentais a esta altura já positivados nas Constituições. Com esse intuito, os intérpretes encontraram na reaproximação com a Moral um caminho mais fácil para o nobre desiderato de constitucionalização do Direito e, por conseguinte, a efetivação dos direitos fundamentais, mormente os sociais, difusos e coletivos. A estrada mais curta, no entanto, nem sempre é a melhor, até porque os direitos fundamentais já estavam positivados, faltavam-lhes apenas serem levados a sério, independentemente de juízos morais, aberturas hermenêuticas exacerbadas ou subjetivismos.

É claro que a judicialização da política e o ativismo judicial se manifestam de diferentes formas nos diversos países e épocas. Interessa aqui perquirir acerca do caso brasileiro. Manoel Gonçalves Ferreira Filho, de maneira pungente, denuncia o que ele chama

\footnotetext{
${ }^{34}$ DAHL, Robert A. Tomada de Decisões em uma Democracia: a Suprema Corte como uma Entidade Formuladora de Políticas Nacionais. Trad. Grupo PrimacyTranslations. Revista de Direito Administrativo. v. 252, 2009, p. 26. Disponível em: <http://bibliotecadigital.fgv.br/ojs/index.php/rda/issue/view/560>. Acesso em: 18 de fev. de 2017.

${ }^{35}$ V. CANOTILHO, José Joaquim Gomes. Um Olhar Jurídico-Constitucional sobre a Judicialização da Política. Revista de Direito Administrativo. v. 245, 2007, p. 91. Disponível em: <http://bibliotecadigital.fgv.br/ojs/index.php/rda/article/view/42122/40814>. Acesso em: 18 de fev. de 2017.
} 
de "Neoconstitucionalismo à brasileira". Dentre outras críticas, possivelmente a de maior relevo é ao que se convencionou chamar de "nova hermenêutica", segundo a qual as normas não teriam um sentido definido, apreensível pelo intérprete. Seria, assim, uma roupagem científica para justificar o ativismo judicial - 'Na verdade, essa 'livre interpretação' serve para que os intérpretes façam prevalecer seus valores, compromissos, posições ideológicas sobre os do legislador", 36

De todo modo, fato é que o Brasil possui uma Constituição prenhe de Direitos carecedores de efetivação e instituídos de maneira aberta, muitas vezes principiológica e programática, mas que no fim das contas são normas jurídicas. A sua implementação, no mais das vezes, exige uma atuação prestacional do Estado, o que tem contra si todos os fatores imagináveis como razões políticas, de desenho institucional e principalmente de ordem financeira. Daí porque a doutrina convencionou tratar a judicialização como uma contingência ${ }^{37}$. Se os demais poderes não cumprem a contento os seus deveres impostos pela Lei Fundamental, o amplo acesso à justiça constitucional oportunizará que o jurisdicionado insatisfeito acione o judiciário e não há nada de errado nisso. O problema reside na legitimidade das respostas dadas por este último poder que, se retirado os seus limites, ameaça tornar-se um órgão hipertrofiado.

O que se quer defender aqui é que a má leitura dos aportes do neocontitucionalismo não coloque a perder todos os ganhos do constitucionalismo liberal e que este risco advém de comportamentos ilegítimos que são a discricionariedade judicial ${ }^{38}$

${ }^{36}$ V. FILHO, Manoel Gonçalves Ferreira. Notas sobre o Direito Constitucional Pós-Moderno, em Particular
sobre Certo Neoconstitucionalismo à Brasileira. Revista de Direito Administrativo. v. 250, 2009, p. 163.
Disponível em: <http://bibliotecadigital.fgv.br/ojs/index.php/rda/article/view/4141/2923>. Acesso em: 19 de fev.
de 2017 .
37 V.,v. g., Luís Roberto Barroso:"A judicialização, no contexto brasileiro, é um fato, uma circunstância que
decorre do modelo constitucional que se adotou, e não um exercício deliberado de vontade política. Em todos os
casos referidos acima, o Judiciário decidiu porque era o que lhe cabia fazer, sem alternativa. Se uma norma
constitucional permite que dela se deduza uma pretensão, subjetiva ou objetiva, ao juiz cabe dela conhecer,
decidindo a matéria" (In BARROSO, Luís Roberto. Judicialização, Ativismo Judicial e Legitimidade
Democrática. [Syn]thesis: Cadernos do Centro de Ciências Sociais. Rio de Janeiro: UERJ, v. 5, n. 1, p. 25.
2012 ).
38 Para Ferrajoli, o que distingue a discricionariedade política da discricionariedade judiciária são as suas fontes
de legitimação: a representação política na primeira e a sujeição à lei na segunda. No Estado de Direito, a
interpretação das leis, a apuração de seu significado e alcance, sempre foi confiada ao Poder Judiciário
justamente porque a separação de poderes é um valor garantista. A função jurisdicional tem um caráter
tendencialmente cognitivo e por isso não pode descambar para a seara das escolhas políticas ou morais, sob pena
de perder a sua legitimação, que não advém da vontade das maiorias, mas da correta verificação dos 
desmedida tendente ao ativismo. A melhor resposta à judicialização é externa ao Direito, qual seja, que as políticas públicas possam ser levadas a cabo pelos órgãos competentes. Uma vez que o fenômeno existe hoje e é uma realidade insuperável pelos mecanismos de justiça - dado que nem mesmo a lei poderá excluir da apreciação do poder judiciário lesão ou ameaça a Direito (artigo 5, XXXV CF) - o problema se apresenta de uma maneira muito difícil de ser equacionada.

Esta celeuma será resolvida pelo compartilhamento entre os operadores do Direito da adoção de métodos claros, objetivos e isentos, na medida do possível, de incursões da moral subjetiva. Não se trata aqui de zerar a tensão existente entre os interesses por mais e melhores políticas públicas em face de governos renitentes ou sem caixa, vez que sociedades democráticas são por definição conflitivas. O que se pretende é apenas aliviar a pressão que as incursões ativistas exercem sobre a democracia, para o que as teorias do mínimo existencial, da reserva do possível e a correta aplicação da regra da proporcionalidade se apresentariam como limites jurídicos eficazes para restabelecer a legitimidade do poder judiciário nesses casos, enquanto pressupostos científicos e metodológicos capazes de espancar qualquer ingerência indevida de fatores externos ao Direito.

3. O Mínimo EXISTENCIAL, A RESERVA do POSSÍvel E A CORRETA APLICAÇÃO DA REGRA DA PROPORCIONALIDADE COMO LIMITES JURÍDICOS EFICAZES À AUTOCONTENÇÃO DO PODER JUDICIÁRIO NA EFETIVAÇÃO DE POLÍTICAS PÚBLICAS

Adverte Virgílio Afonso da Silva que o conceito de mínimo existencial pode ser encarado em diversos sentidos, dentre os quais destaca: i) aquilo que é garantido pelos direitos sociais - ou seja, eles seriam garantidores de apenas um mínimo existencial; ii) o conteúdo dos direitos sociais que possa ser judicializado, i. e., ainda que os direitos sociais possam garantir mais, ao judiciário somente seria dado realizar o conteúdo correspondente ao

pressupostos (de fato e de Direito) da decisão. V. FERRAJOLI, Luigi. Garantismo: Uma Discussão sobre Direito e Democracia. Trad. Alexander Araújo de Souza. Rio de Janeiro: Editora Lumen Juris, 2012, p. 67-71. 
mínimo existencial e iii) o mesmo que conteúdo essencial, que não corresponderia, necessariamente, com a sua justiciabilidade nem com a inteireza do conteúdo do direito. ${ }^{39}$

Cristina M. M. Queiroz aduz que o Poder Legislativo, ao proceder à concretização dos direitos fundamentais, deve estar vinculado a um "limite último", "extremo" e "intransponível”. Quando na "função positiva" da concretização dos direitos fundamentais, é que se formula o "conteúdo essencial", podendo este "[...] representar nas mãos do juiz constitucional um instrumento valioso, $v$. $g$., em razão da cláusula da 'dignidade da pessoa humana' do artigo $1^{\circ}$ da Constituição [...]" - referindo-se à Constituição Portuguesa (1976), cujo artigo primeiro coincide por abrigar a dignidade da pessoa humana tal como na Constituição Brasileira. ${ }^{40}$ Trata a autora lusitana, portanto, do núcleo essencial do direito, aquele conteúdo que não pode ter arranhada a sua eficácia, ainda que por omissão, sem que se esteja por negar a sua normatividade e, por conseguinte, incorrer em inconstitucionalidade.

A maneira mais comum de se chegar ao núcleo essencial de um direito fundamental tem sido apurar a observância do princípio inscrito no artigo 1, III da CF/88. Nas palavras da Ministra Carmen Lúcia, a Constituição Federal Brasileira“[...] centralizou a dignidade da pessoa humana como ponto de partida e ponto de chegada da interpretação do direito e da aplicação da ação desse direito em qualquer nível e em qualquer seara." ${ }^{41}$ Não obstante, é forçoso reconhecer que nem todos os direitos fundamentais têm como fundamento direto a dignidade da pessoa humana. Nesses casos, cumpriria fazer uma análise à luz das necessidades de cada pessoa e de seu núcleo familiar, inventariando-se, inclusive, o conjunto de conquistas já sedimentadas sem excluir outras circunstâncias que possam servir de roteiro ao intérprete. ${ }^{42}$ Perceba que se estaria assim a referir a aferição do conteúdo de mínimo existencial à carga argumentativa que se lhe empresta, o que reforça a possibilidade de ingerência do poder de julgar na seara própria dos poderes executivo e legislativo. Portanto,

\footnotetext{
${ }^{39}$ SILVA, Virgílio Afonso da.Direitos Fundamentais: Conteúdo Essencial, Restrições e Eficácia. $2^{\mathrm{a}}$ ed. São Paulo: Malheiros, 2010, p. 204-205.

${ }^{40}$ QUEIROZ, Cristina M. M. Direitos Fundamentais (Teoria Geral). Coimbra: Coimbra Editora, 2002, p. 215216.

${ }^{41}$ ROCHA, Carmen Lúcia Antunes. A Dignidade da Pessoa Humana e o Mínimo Existencial. Revista de Direito Administrativo. $\quad$ v. 252, 2009, p. 21. Disponível em: <http://bibliotecadigital.fgv.br/ojs/index.php/rda/article/view/7953/6819>. Acesso em: 18 de mar. de 2017.

${ }^{42}$ V. FIGUEIREDO, Mariana Filchtiner; SARLET, Ingo Wolfgang. Reserva do Possível, Mínimo Existencial e Direito à Saúde: Algumas Aproximações. In SARLET, Ingo Wolfgang; TIMM, Luciano Benetti (Orgs.). Direitos Fundamentais: Orçamento e "Reserva do Possivel". $2^{\mathrm{a}}$ ed. Porto Alegre: Livraria do Advogado, 2010,p. 26-27.
} 
seria mais conveniente assumir como conteúdo mínimo de um direito fundamental, hábil a exigir, até mesmo pela via jurisdicional, a sua implementação, a eficácia estritamente necessária a retirar o cidadão de eventual estado inconstitucional de indignidade.

De fato, como advertiu Virgílio, o mínimo existencial não corresponde a todo o sentido que possa ser extraído de uma norma definidora de direito social fundamental, mas é possível advogar que o seu significado de conteúdo essencial, na maior parte dos casos, condiz com os limites de atuação do órgão julgador no momento de efetivá-la. Nem mesmo a reserva do possível e a regra da proporcionalidade autorizam a violação deste núcleo. Mas, ainda assim, o mínimo existencial não é congruente com a justiciabilidade do direito fundamental, porque este pode ser homenageado, no caso concreto, com uma efetivação mais alargada do que o seu conteúdo essencial. Ausentes as hipóteses de reserva do possível ou da violação da regra da proporcionalidade, o julgador deve buscar na aplicação da norma definidora de direito fundamental a máxima eficácia possível. ${ }^{43}$

Eis, portanto, que a Teoria do Mínimo Existencial é muito útil e necessária, todavia,insuficiente, quando isoladamente considerada, para elidir as incursões indevidas do julgador na seara própria dos demais poderes, uma vez que ela é informadora apenas dos limites do sacrifício do direito, e não da ampliação de sua eficácia. Daí a necessidade de se compreender melhor a Teoria da Reserva do Possível.

Se uma obrigação é impossível, então ela é inexigível. Esta premissa que norteia o Direito Obrigacional desde as compilações de Justiniano deve se aplicar também ao Estado. ${ }^{44}$ Em que pese a ideia de impossibilium nulla obligatio est ser demasiadamente antiga, a construção teórica da "Reserva do Possível" deita raízes na Alemanha da década de 70. A jurisprudência do Tribunal Constitucional Federal da Alemanha assentou entendimento no sentido de que "[...]mesmo em dispondo o Estado dos recursos e tendo o poder de disposição,

\footnotetext{
43 “"...] tanto quanto qualquer outro direito, um direito social também deve ser realizado na maior medida possível, diante das condições fáticas e jurídicas presentes. [...] Aqui, mais uma vez, o conceito de mandamento de otimização aparece em sua inteireza" (InSILVA, Virgílio Afonso da. Direitos Fundamentais: Conteúdo Essencial, Restrições e Eficácia. $2^{\mathrm{a}}$ ed. São Paulo: Malheiros, 2010, p. 205).

${ }^{44}$ LOPES, José Reinaldo de Lima. Em Torno da "Reserva do Possível". In SARLET, Ingo Wolfgang; TIMM, Luciano Benetti (Orgs.). Direitos Fundamentais: Orçamento e "Reserva do Possivel". $2^{\mathrm{a}}$ ed. Porto Alegre: Livraria do Advogado, 2010, p. 159.
} 
não se pode falar em uma obrigação de prestar algo que não se mantenha nos limites do razoável". 45

A Reserva do Possível apresentaria uma dimensão tríplice: i) a efetiva disponibilidade fática dos recursos para a efetivação dos direitos fundamentais; ii) a disponibilidade jurídica dos recursos materiais e humanos, ou seja, competência material do ente administrativo e alocação de recurso específico e iii) proporcionalidade da prestação. ${ }^{46}$

Veja, portanto, que a regra da proporcionalidade está a balizar até mesmo a ideia de reserva do possível. Contudo, é preciso cindir as duas coisas, de modo a detalhar os critérios com o maior rigor, pois é esse rigorismo que fornecerá à decisão judicial legitimidade. Não é a quantidade de argumentos retóricos, a aceitabilidade social ou o peso de fundamentos às vezes meta-jurídicos que apontam para a correção da decisão, mas a verificação de que pressupostos compartilháveis pela comunidade jurídica permitem chegarse à mesma conclusão, qualquer que seja a ideologia do intérprete ou a sua vontade política.

Dada a necessidade de se aliar os dois instrumentais: reserva do possível e proporcionalidade e considerando que esta última compreende um raciocínio mais exaustivo e complexo, convém aqui reduzir a Reserva do Possível a dois requisitos essenciais: i) competência material constitucional para que o ente demandado preste o direito fundamental afetado pela ausência de políticas públicas e ii) existência de previsão orçamentária específica para aquele tipo de gasto. ${ }^{47}$

A CF/88 adotou um sistema complexo a perseguir o melhor equilíbrio possível entre os entes públicos num desenho federativo nada ortodoxo. Com esse desígnio, valeu-se,

${ }^{45}$ FIGUEIREDO, Mariana Filchtiner; SARLET, Ingo Wolfgang. Reserva do Possível, Mínimo Existencial e Direito à Saúde: Algumas Aproximações. In SARLET, Ingo Wolfgang; TIMM, Luciano Benetti (Orgs.). Direitos Fundamentais: Orçamento e "Reserva do Possivel". $2^{\mathrm{a}}$ ed. Porto Alegre: Livraria do Advogado, 2010, p. 29.

${ }^{46}$ FIGUEIREDO, Mariana Filchtiner; SARLET, Ingo Wolfgang. Reserva do Possível, Mínimo Existencial e Direito à Saúde: Algumas Aproximações. In SARLET, Ingo Wolfgang; TIMM, Luciano Benetti (Orgs.). Direitos Fundamentais: Orçamento e "Reserva do Possivel". $2^{\mathrm{a}}$ ed. Porto Alegre: Livraria do Advogado, 2010, p. 30 .

47 "Os direitos econômicos e sociais existem, portanto, sob a "reserva do possível" ou da "soberania orçamentária do legislador", ou seja, da reserva da lei instituidora das políticas públicas, da reserva da lei orçamentária e do empenho da despesa por parte da Administração. A pretensão do cidadão é a política pública, e não à adjudicação individual de bens públicos" (In TORRES, Ricardo Lobo. O Mínimo Existencial, os Direitos Sociais e os Desafios de Natureza Orçamentária. In SARLET, Ingo Wolfgang; TIMM, Luciano Benetti (Orgs.). Direitos Fundamentais: Orçamento e "Reserva do Possível". $2^{\mathrm{a}}$ ed. Porto Alegre: Livraria do Advogado, 2010, p. 74). 
dentre outras coisas, de uma repartição de competências fundada na enumeração dos poderes da União (artigos 21 e 22), com poderes remanescentes para os Estados (artigo 25, parágrafo $1^{\circ}$ ) e poderes definidos indicativamente para os Municípios (artigo 30), combinando possibilidades de delegação (artigo 22, parágrafo único), áreas comuns de atuação atribuída a todos os entes (artigo 23) e "setores concorrentes entre União e Estados em que a competência para estabelecer políticas gerais, diretrizes gerais ou normas gerais cabe à União, enquanto se defere aos Estados e até aos Municípios a competência suplementar". ${ }^{48}$

Celso Ribeiro Bastos aduz que "O traço principal que marca profundamente a nossa já capenga estrutura federativa é o fortalecimento da União relativamente às demais pessoas integrantes do sistema". ${ }^{49}$ Some-se a essa distorção a inclusão dos Municípios como entes federados e, portanto, dotados de deveres Constitucionais. Paulo Bonavides é taxativo em dizer: "Não conhecemos uma única forma de união federativa contemporânea onde o princípio da autonomia municipal tenha alcançado grau de caracterização política e jurídica tão alta e expressiva [...]". ${ }^{50}$ A par de Bastos e Bonavides, que são entusiastas da elevação dos municípios a este patamar até então inaudito, José Afonso da Silva tece duras críticas a essa opção constitucional. Para ele, a característica básica de qualquer Federação está em o poder governamental se distribuir em unidades regionais, o que na maior parte dos lugares é feita de maneira dual, ou seja, formando duas órbitas de governo: a central e as regionais sobre o mesmo povo e o mesmo território. ${ }^{51}$

Em qualquer caso, prevalece que o Brasil possui três esferas de poder político e administrativo sob o guarda-chuva da mesma Constituição Federal que distribui entre eles, de uma maneira mais ou menos compreensível, as obrigações para com os seus cidadãos, dentre elas muitas prestacionais. Paralelamente, estatui competências tributárias a todos eles e ordena a repartição de suas receitas com os demais, o que nem sempre resulta no equilíbrio entre a quantidade de recursos auferidos por cada ente e suas competências outorgadas pela Lei Fundamental, naquilo que se convencionou chamar de "Federalismo Cooperativo". Embora muito lembrado pelos tributaristas, essa característica própria da forma de Estado tupiniquim

\footnotetext{
${ }^{48}$ SILVA. José Afonso da.Curso de Direito Constitucional Positivo. 25 a ed. São Paulo: Malheiros, 2005, p. 479.

${ }^{49}$ BASTOS, Celso Ribeiro. Curso de Direito Constitucional. $22^{\mathrm{a}}$ ed. São Paulo: Saraiva, 1999, p. 330.

${ }^{50}$ BONAVIDES, Paulo. Curso de Direito Constitucional. 15 ed. São Paulo: Malheiros, 2004, p. 347.

${ }^{51}$ SILVA. José Afonso da.Curso de Direito Constitucional Positivo. 25 a ed. São Paulo: Malheiros, 2005, p. 640.
} 
tem repercussões muito significativas quanto à concretização de políticas públicas. ${ }^{52}$ Neste quadro, já demasiadamente desfigurado, em nada contribui o Poder Judiciário comportar-se como um "ordenador de despesas" sem nenhuma articulação com os órgãos e agentes definidores da receita. Não é tarefa fácil, dada a complexidade do sistema brasileiro, identificar neste cipoal de entes e competências qual deles deverá suportar financeiramente uma decisão judicial concretizadora de políticas públicas. Mas é de extremada importância que se chegue a esse termo, sob pena de os entes políticos passarem a ser demandados por obrigações que não são suas e os juízes porem abaixo de vez um sistema que, de resto, já é tido por alguns como, na diç̧ão de Celso Ribeiro Bastos, "capenga".

Tem-se por obstada pela Reserva do Possível, v. g., uma decisão judicial que obrigue a municipalidade a reformar determinado estabelecimento prisional, ainda que localizado em seu território. A Constituição assegura ao preso a sua integridade física e moral (artigo 5, XLIX) e, considerando a eficácia horizontal dos direitos fundamentais ${ }^{53}$, este é um dever para o qual todos os cidadãos e entes públicos devem colaborar, até como corolário do Princípio da Dignidade da Pessoa Humana (artigo 1, III CF). Mas não é certo impor essa obrigação específica ao município, vez que a Constituição atribui a competência legislativa sobre Direito Penitenciário à União, Estados e DF (artigo 24, I CF), recaindo sobre os últimos a competência material residual (artigo 25 , par. $1^{\circ} \mathrm{CF}$ ).

No tocante à exigência de previsão orçamentária para a despesa decorrente de imposição judicial, cumpre anotar que a concretização de políticas públicas, no mais das vezes, não se realiza pela expedição de precatórios (artigo $100 \mathrm{CF}$ ). É uma demanda por obras, compras governamentais, prestação de serviços que exigem a realização de concursos públicos e nomeação de servidores - atos próprios da função administrativa. A Constituição é

\footnotetext{
52 “Como visto, a Constituição Federal de 1988 instituiu expressamente o federalismo cooperativo dispondo matérias de competência comum entre todos os entes federados. Isto se justifica 'pelo fato de que num Estado intervencionista e voltado à implementação de políticas públicas, as esferas subnacionais não têm mais como analisar e decidir, originariamente, sobre inúmeros setores da atuação estatal, que necessitam de tratamento uniforme em escala nacional': em assuntos da ordem econômica e social há necessidade de unidade no planejamento e direção das tarefas [...]" (In BERCOVICI, Gilberto [Coord.]. O Federalismo Brasileiro e os Limites da Competência Legislativa e Administrativa: Memórias de Pesquisa. Revista Jurídica. Brasília. v. 10, n. 90, abr.-maio, p. 12-13, 2008).

53“"[...] somos forçados a concluir que a eficácia dos direito fundamentais não é apenas vertical (: relação cidadão/Estado), mas também horizontal (: relação cidadão/cidadão). Quer dizer, exerce-se ainda no domínio jurídico-privado. É o que se designa por "efeito externo" dos direitos fundamentais" (In QUEIROZ, Cristina M. M. Direito Fundamentais (Teoria Geral). Coimbra: Coimbra Editora, 2002,p. 277).
} 
taxativa ao vedar o início de programas ou projetos não incluídos na lei orçamentária anual e a realização ou a assunção de obrigações diretas que excedam os créditos orçamentários ou adicionais (artigo 167, I e II CF). Deflui de um silogismo trivial que a ausência de previsão orçamentária específica e suficiente para aquele tipo de gasto torna impossível qualquer obrigação positiva constituída pelo Poder Judicante ao arrepio dessa exigência intrínseca à Teoria da Reserva do Possível.

Não fosse pela genialidade teórica dos alemães e dos doutrinadores brasileiros que tratam do assunto, essa condição estaria inexoravelmente presente, pois não se pode sequer licitar obras e serviços sem a previsão de recursos orçamentários (artigo 7, par. 2, III Lei 8.666/93). Logo, nenhum comando judicial para que o Estado implemente políticas públicas será exequível se não encontrar na Lei Orçamentária alguma dotação destinada para aquele tipo gasto, o que deverá ser considerado pelo julgador no momento de decidir.

Aliando-se as Teorias do Mínimo Existencial e da Reserva do Possível tal como apresentadas, já se poderia evitar uma enormidade de decisões danosas à separação das funcionalidades do Poder. Entretanto, não excede acrescer à lista de mecanismos de contenção a serem adotados pelo julgador, aquele que talvez seja o mais completo e sublime deles: a Regra da Proporcionalidade.

Preliminarmente, advirta-se que a Regra da Proporcionalidade (lato sensu) de que aqui se fala não se confunde com o Princípio da Razoabilidade nem com a proporcionalidade em sentido estrito. O primeiro se diferencia do segundo não só pela sua origem, mas também pela sua estrutura. Para alguns o Princípio da Razoabilidade teria sua gênese remota na Carta Magna de 1215 (Luis Roberto Barroso, p. ex.), para outros, não estaria presente em nenhum documento legislativo, mas manifestara-se pela primeira vez no Caso Wednesbury de 1948 (Willis Santiago Guerra Filho, p. ex.). É certo, porém, que se desenvolveu primeiramente na Inglaterra, essa teoria. Não obstante inúmeras confusões teóricas e terminológicas que se sucederam após a sua exportação para o mundo, principalmente no Brasil, prevalece que por Princípio da Razoabilidade deve ser entendido como uma fórmula para rejeitar atos que sejam excepcionalmente irrazoáveis. Trata-se de algo "[...] muito menos intenso do que os testes que a regra da proporcionalidade exige, destinando-se meramente a afastar atos absurdamente irrazoáveis. [...]pois, para ser 
considerado desproporcional, não é necessário que um ato seja extremamente irrazoável ou absurdo. ${ }^{~} 54$ É claro que o Princípio da Razoabilidade está também a fornecer balizas para a autocontenção do Poder Judiciário, na medida em que o intérprete/aplicador não está autorizado a tomar decisões escatológicas ou absurdas. Contudo, não convém neste curto espaço se alongar sobre este assunto, vez que a observação da regra da proporcionalidade será suficiente para espancar decisões desse quilate.

A Proporcionalidade Stricto Sensu atrai a metáfora da balança para a sua conceituação, pela qual se deveria aferir o peso dos bens jurídicos em jogo - ponderação - e determinar o prevalecimento de um sobre outro, no caso concreto. "No caso específico do exame da proporcionalidade de intervenções em direitos fundamentais, a ponderação se dá entre vantagens e desvantagens jurídicas para os bens jurídicos encontrados atrás da intervenção e do propósito perseguido pelo Estado". ${ }^{55}$ Embora não se confundam, conforme se verá adiante, a proporcionalidade em sentido estrito é informadora da Regra da Proporcionalidade em Sentido Amplo, na medida em que é aceita por esmagadora parte da doutrina e das jurisprudências de diversos países como a terceira sub-regra de aplicação desta que nada mais é do que um critério de interpretação e aplicação do Direito, "empregada especialmente nos casos em que um ato estatal, destinado a promover a realização de um direito fundamental ou de um interesse coletivo, implica a restrição de outro ou outros direitos fundamentais" 56 . Nestes casos, Willis Santiago Guerra Filho aproxima a proporcionalidade em sentido estrito da proteção do mínimo existencial, determinando-se o estabelecimento de uma “[...] correspondência entre o fim a ser alcançado por uma disposição normativa e o meio empregado, que seja o melhor possível. [...] que não se fira o conteúdo essencial

\footnotetext{
${ }^{54}$ SILVA, Virgílio Afonso da. O Proporcional e o Razoável. Revista dos Tribunais. v. 798, 2002, p. 29-30. Lembra ainda Virgílio que não há mais cabimento para referir a regra da proporcionalidade ao uso do conceito de "Proibição do Excesso". "Conquanto a regra da proporcionalidade ainda seja predominantemente entendida como instrumento de controle contra excesso dos poderes estatais, cada vez mais vem ganhando importância a discussão sobre a sua utilização para finalidade oposta, isto é, como instrumento contra a omissão ou contra a ação insuficiente dos poderes estatais" (InSILVA, Virgílio Afonso da. O Proporcional e o Razoável. Revista dos Tribunais. v. 798, 2002, p. 27).

${ }^{55}$ DIMOULIS, Dimitri; MARTINS, Leonardo. Teoria Geral dos Direitos Fundamentais. São Paulo: Revista dos Tribunais, 2008, p. 224.

${ }^{56}$ SILVA, Virgílio Afonso da. O Proporcional e o Razoável. Revista dos Tribunais. v. 798, 2002, p. 24.
} 
(Wesensgehalt) de direito fundamental, com o desrespeito intolerável da dignidade humana $[\ldots]^{\prime \prime 57}$.

"Regra" da Proporcionalidade, porque não se pode concebê-la, em sua estrutura, como um princípio, pois este é uma "[...] norma que exige que algo seja realizado na maior medida possível diante das condições fáticas e jurídicas do caso concreto" ${ }^{\text {58 }}$. Para Virgílio Afonso da Silva, a proporcionalidade não é, de fato, uma regra de conduta, mas uma "regra acerca da aplicação de outras regras" 59 .

Não sem muitas divergências, após longo período de maturação, desde os primeiros trabalhos na Alemanha, hoje é possível dizer que existe um consenso acerca da estrutura da proporcionalidade lato sensu, que seria representada por três sub-regras: i) adequação; ii) necessidade e iii) proporcionalidade stricto sensu. ${ }^{60}$

A exigência de adequação determina que "[...] dentro do faticamente possível, o meio escolhido se preste para atingir o fim estabelecido, mostrando-se, assim, 'adequado' ${ }^{61}$. DimitriDimoulis e Leonardo Martins aludem a uma conexão empírica entre "[...] o estado de coisas conseguido pela intervenção e o estado de coisas no qual o propósito puder ser considerado realizado" 62 . No seu entendimento, "[...] todos os meios empregados pelo Estado e que não implicarem essa conexão empiricamente comprovável são considerados

\footnotetext{
${ }^{57}$ FILHO, Willis Santiago Guerra. Processo Constitucional e Direitos Fundamentais. $5^{\text {a }}$ ed. São Paulo: RCS Editora, 2007, p. 88.

${ }^{58}$ SILVA, Virgílio Afonso da.Direitos Fundamentais: Conteúdo Essencial, Restrições e Eficácia. $2^{\mathrm{a}}$ ed. São Paulo: Malheiros, 2010, p. 168.

${ }^{59}$ Idem.

${ }^{60}$ V. v. g. SILVA, Virgílio Afonso da.Direitos Fundamentais: Conteúdo Essencial, Restrições e Eficácia. $2^{\mathrm{a}}$ ed. São Paulo: Malheiros, 2010, p. 169-178 e SILVA, Virgílio Afonso da. O Proporcional e o Razoável. Revista dos Tribunais. v. 798, 2002, p. 34-41. DimitriDimoulis e Leonardo Martins concebem quatro sub-regras: i) licitude do propósito perseguido; ii) licitude do meio utilizado; iii) adequação do meio utilizado e iv) necessidade do meio utilizado (v. DIMOULIS, Dimitri; MARTINS, Leonardo. Teoria Geral dos Direitos Fundamentais. São Paulo: Revista dos Tribunais, 2008, p. 197-223). Para Willis Santiago Guerra Filho, o Tribunal Constitucional Alemão se valeria "[...] do que a doutrina aponta como a tríplice manifestação do "mandamento da proporcionalidade'(VerhältnissmäBigkeitsgebot), também chamado de 'proibição de excesso'(ÜbermaBverbot): 'adequação'(Geeignetheit), 'exigibilidade' (Erforderlichkeit) e 'proporcionalidade em sentido estrito'(VerhältnismäBigkeit i. e. S.)" (In FILHO, Willis Santiago Guerra. Princípio da Proporcionalidade e Devido Processo Legal. In SILVA, Virgílio Afonso da (Org.). Interpretação Constitucional. São Paulo: Malheiros, 2007, p. 262).

${ }^{61}$ FILHO, Willis Santiago Guerra. Processo Constitucional e Direitos Fundamentais. $5^{\text {a }}$ ed. São Paulo: RCS Editora, 2007, p. 89.

${ }^{62}$ DIMOULIS, Dimitri; MARTINS, Leonardo. Teoria Geral dos Direitos Fundamentais. São Paulo: Revista dos Tribunais, 2008, p. 206.
} 
desproporcionais e, por via de consequência, inconstitucionais"63. Para Virgílio Afonso da Silva, por outro lado, não chega a tanto. Este autor entende não ser exigível que o objetivo seja alcançado em sua inteireza por determinado meio. Adequado é “[...] também o meio com cuja utilização a realização de um objetivo é fomentada, promovida, ainda que o objetivo não seja completamente realizado"64. Essa observação de Virgílio parece ser a mais acertada, tanto quanto a indispensável assertiva de Willis Santiago Guerra Filho, que analisando o fenômeno sob a jurisprudência do Tribunal Constitucional Alemão, assevera que "O BVerfGE reconhece, porém, que o estabelecimento de objetivos e de meios para alcança-los é um problema de política legislativa (ou administrativa) que a ele não cabe resolver, em substituição às autoridades constitucionalmente competentes, [...]"65.

Essa afirmação de Willis tem especial relevância para o presente trabalho, pois, quando uma decisão judicial tendente a efetivar um direito fundamental ordene a implementação de políticas públicas, o aplicador/intérprete deve verificar se o seu comando não está se contrapondo a uma opção legislativa ou administrativa legítima (não inconstitucional). Nesse sentido, determinar a vacinação contra determinada moléstia a pessoas de todas as faixas etárias é meio adequado à obtenção do direito à saúde, mas que não poderá prosperar, via judiciário, se a conveniência de se imunizar apenas o grupo de risco e combater o agente transmissor da doença para prevenir os demais casos for a opção adotada pelas autoridades sanitárias, calcada em estudos científicos que comprovem ser esta também uma via adequada.

A sub-regra da "necessidade" compreende analisar se há outro meio que o Estado possa utilizar e que satisfaça as condições de ser menos gravoso para o titular do direito que sofra a limitação e ter eficácia semelhante ao meio escolhido que haja passado

\footnotetext{
${ }^{63}$ Idem.

${ }^{64}$ SILVA, Virgílio Afonso da. O Proporcional e o Razoável. Revista dos Tribunais. v. 798, 2002, p. 36. Aduz Virgílio: "A exigência de realização completa do fim perseguido é contraproducente, já que dificilmente é possível saber com certeza, de antemão, se uma medida realizará, de fato, o objetivo a que se propõe. Muitas vezes o legislador é obrigado a agir em situações de incertezas empíricas, é obrigado a fazer previsões que não sabe e serão realizadas ou, por fim, esbarra nos limites da cognição. Nesses casos, qualquer exigência de plena realização de algo seria uma exigência impossível de ser cumprida. Por isso a preferência pela primeira alternativa, que, de resto, é também aquela apoiada pela maioria da doutrina" (InSILVA, Virgílio Afonso da.Direitos Fundamentais: Conteúdo Essencial, Restrições e Eficácia. $2^{\text {a }}$ ed. São Paulo: Malheiros, 2010, p. 170).

${ }^{65}$ FILHO, Willis Santiago Guerra. Princípio da Proporcionalidade e Devido Processo Legal. In SILVA, Virgílio Afonso da (Org.). Interpretação Constitucional. São Paulo: Malheiros, 2007, p. 262-263.
} 
pelo crivo da adequação ${ }^{66}$. "A diferença entre o exame da necessidade e o da adequação é clara: o exame da necessidade é um exame imprescindivelmente comparativo, enquanto que o da adequação é um exame absoluto" 67 . A necessidade, também chamada "exigibilidade" por alguns como Willis Santiago Guerra Filho, “[...] costuma ser associada à busca pelo meio mais suave (milderes Mittel), dentre vários possíveis, para atingir o fim buscado - no que se reconhece haver grande margem de ação (Handlungs-spielraum) [...]"68. Assim deve se portar o julgador quando instado a se manifestar sobre a omissão do Estado em dar vazão a um direito fundamental prestacional. Nos tradicionais casos de judicialização da saúde, p. ex., se o medicamento não fornecido pelo SUS for pleiteado em juízo pelo cidadão, após ter passado pelo crivo da reserva do possível, deverá o intérprete/aplicador indagar ainda se não existe outro medicamento equivalente no mercado que seja igualmente eficaz e financeiramente menos custoso para o Erário. Havendo-o, o Poder Judiciário somente poderá obrigar a Administração Pública a fornecer este remédio alternativo, se, e somente se, não colocar em cheque o mínimo existencial, ou seja, a dignidade do paciente (imagine que se trate de um medicamento experimental ou com agressivos efeitos colaterais, p. ex.).

Finalmente, a Proporcionalidade em Sentido Estrito, conforme adiantado supra, constitui para muitos nada mais do que a ponderação dos bens jurídicos em liça, aferir, quando um dos bens tiver de preponderar, qual deles poderá ser prestigiado representando o menor sacrifício do outro. Virgílio Afonso da Silva sugere exemplo bastante elucidativo do que se pretende com essa sub-regra. Imagine-se que o legislador aprove um projeto de lei que, em homenagem ao Direito Fundamental à Intimidade, proíba qualquer forma de jornalismo investigativo. Neste caso, a medida será adequada e dificilmente se imaginaria algo tão eficaz e menos danoso à liberdade de imprensa. ${ }^{69}$ Não passando pelo terceiro crivo da proporcionalidade, referida lei, evidentemente inconstitucional, poderia ser tida por legítima. Willis Santiago Guerra Filho fala expressamente em "sopesamento", “[...] colocando de um

\footnotetext{
${ }^{66}$ V. DIMOULIS, Dimitri; MARTINS, Leonardo. Teoria Geral dos Direitos Fundamentais. São Paulo: Revista dos Tribunais, 2008, p. 215.

${ }^{67}$ SILVA, Virgílio Afonso da. O Proporcional e o Razoável. Revista dos Tribunais. v. 798, 2002, p. 38.

${ }^{68}$ FILHO, Willis Santiago Guerra. Princípio da Proporcionalidade e Devido Processo Legal. In SILVA, Virgílio Afonso da (Org.). Interpretação Constitucional. São Paulo: Malheiros, 2007, p. 263.

${ }^{69}$ V. SILVA, Virgílio Afonso da.Direitos Fundamentais: Conteúdo Essencial, Restrições e Eficácia. $2^{\mathrm{a}}$ ed. São Paulo: Malheiros, 2010, p. 175.
} 
lado, o interesse no bem-estar da comunidade e, de outro, as garantias dos indivíduos que a integram, a fim de evitar o beneficiamento demasiado de um, em detrimento de outro"70.

No exemplo de Virgílio, a lei de censura não poderia ser tida por proporcional, e por isso ela é inconstitucional, porque confere um peso demasiado à intimidade, subjugando sobremaneira outro direito fundamental que é a liberdade de imprensa. “[...] não é necessário que a medida atinja o chamado núcleo essencial de algum direito fundamental. [...] basta que os motivos que fundamentaram a adoção da medida não tenham peso suficiente para justificar a restrição a direito fundamental atingido"71. A toda a evidência que a técnica do sopesamento, que é central neste ponto, é uma porta aberta às teorias da argumentação, dado o seu alargado conteúdo axiológico. Daí porque alguns autores pretendem excluir essa subregra, sob o argumento de que "[...] seria simplesmente a substituição da subjetividade do legislador pela subjetividade do juiz"72. Este é o caso de Dimitri Dimoulis e Leonardo Martins, para os quais " [...] falta uma medida objetiva, cientificamente comprovada para a ponderação, por mais rebuscados que pareçam os modelos apresentados por Alexy e seus seguidores" ${ }^{, 73}$. A crítica é pertinente e aqui reside a principal origem do subjetivismo dos intérpretes/aplicadores do Direito no Brasil. Alguns dirão que se trata de má leitura da obraAlexy, outros que em nenhuma circunstância é legítimo atribuir ao juiz o poder de dizer qual Direito Fundamental poderia ter maior peso no caso concreto, que isso não seria possível de ser desenvolvido com um grau de objetividade aceitável. É de fato um problema, mas não se pode olvidar da advertência feita por Virgílio, de que podem existir medidas adequadas e necessárias, porém completamente desarrazoadas. Mantendo este campo aberto para o debate, cumpre aqui reconhecer a Proporcionalidade em Sentido Estrito como método idôneo à autocontenção do Poder Judiciário na efetivação de políticas públicas, porém fazer um apelo para que o "sopesamento" seja feito da maneira mais objetiva e racional possível.

A proporcionalidade em sentido estrito está a referir uma garantia contra os abusos, e não uma carta branca ao julgador para tentar moldar o mundo segundo a sua régua

\footnotetext{
${ }^{70}$ FILHO, Willis Santiago Guerra. Princípio da Proporcionalidade e Devido Processo Legal. In SILVA, Virgílio Afonso da (Org.). Interpretação Constitucional. São Paulo: Malheiros, 2007, p. 263.

${ }^{71}$ SILVA, Virgílio Afonso da. O Proporcional e o Razoável. Revista dos Tribunais. v. 798, 2002, p. 41.

72 SILVA, Virgílio Afonso da.Direitos Fundamentais: Conteúdo Essencial, Restrições e Eficácia. $2^{\mathrm{a}}$ ed. São Paulo: Malheiros, 2010, p. 177.

${ }^{73}$ DIMOULIS, Dimitri; MARTINS, Leonardo. Teoria Geral dos Direitos Fundamentais. São Paulo: Revista dos Tribunais, 2008, p. 226.
} 
de valores. O intérprete/aplicador deve ter em mente que as opções legislativas e administrativas devem prevalecer quando não forem flagrantemente ilegais ou inconstitucionais, ainda que sejam tidas por seu olhar subjetivo, da mídia ou ainda que por toda a comunidade como uma má escolha, do ponto de vista político. Pode-se arriscar a dizer que a necessidade do chamado "sopesamento", para fins de aferição da proporcionalidade, teria suficientemente alcançada a sua finalidade se, não resultando a preponderância de um direito (formulado como um princípio, gize-se) sobre o outro em uma situação desarrazoada (extremada) ou prejudicial à dignidade dos indivíduos (mínimo existencial) prevalecesse sempre a opção legislativa ou administrativa, resultando outra a ser adotada pelo Poder Judiciário, ainda que mais inteligente, eficiente ou socialmente aceita, em indevida substituição das funcionalidades de um poder por outro.

\section{CONCLUSÃO}

Depreende-se do presente estudo que o Constitucionalismo Clássico está assentado em valores que precisam ser preservados, não obstante a sanha ativista, que vem embalada pela vulgarização do neoconstitucionalismo. Como se pode observar, a judicialização das políticas públicas é na verdade justificável, diante da inércia dos poderes governamentais - Executivo e Legislativo. Não obstante, caso esse processo transcorra sem limites, ensaia-se um agravamento do problema fiscal brasileiro e aprofundamento da crise de representatividade. Deve-se ter em mente que a concretização de políticas públicas pelos juízes encontra respaldo de legitimidade tão somente na correção jurídica da decisão, e não na vontade popular, o que sugere maior cautela diante de um procedimento que deve ser encarado como atípico e excepcional.

Assim, após revisitar fenômenos clássicos do cotidiano do Estado e acrescentar-lhes alguns mais contemporâneos que se manifestam claramente na cena jurídica brasileira, é possível concluir que a maneira mais efetiva de se solucionar a questão posta seria pela autocontenção do Poder Judiciário, mediante um procedimento criterioso a fim de orientar os juízes na adoção de tais medidas. Deste modo, propõe-se que, antes de decidir implementar uma demanda por política pública, o intérprete observe os limites do sacrifício do Direito, método consubstanciado na Teoria do Mínimo Existencial; ato contínuo, indaguese da existência de recurso orçamentário apto a financiar o que está a ser decidido e se existe 
competência material para o ente demandado realizar aquela tarefa - corolários da Reserva do Possível; e, por fim, submeta a pretensão ao crivo da Regra da Proporcionalidade por meio de suas sub-regras: adequação, necessidade e proporcionalidade em sentido estrito.

\section{REFERÊNCIAS}

ABBOUD, Georges. Jurisdição Constitucional e Direitos Fundamentais. São Paulo: Revista dos Tribunais, 2011.

BOBBIO, Norberto. A Era dos Direitos. Trad. Carlos Nelson Coutinho. São Paulo: Elsevier, 2004.

.Liberalismo e Democracia. Trad. Marco Aurélio Nogueira. São Paulo: Brasiliense, 2000.

O Futuro da Democracia: Uma Defesa das Regras do Jogo. 6a ed. Trad. Marco Aurélio Nogueira. Rio de Janeiro: Paz e Terra, 1986.

BONAVIDES, Paulo. Curso de Direito Constitucional. 15ª ed. São Paulo: Malheiros, 2004. Do Estado Liberal ao Estado Social. 11 a ed. São Paulo: Malheiros, 2013. Teoria Constitucional da Democracia Participativa. São Paulo: Malheiros, 2001.

CADEMARTORI, Luiz Henrique Urquhart. DUARTE, Francisco Carlos. Hermenêutica e Argumentação Neoconstitucional. São Paulo: Atlas, 2009.

CANOTILHO, José Joaquim Gomes. Constituição Dirigente e Vinculação do Legislador: Contributo para a Compreensão das Normas Constitucionais Programáticas. Coimbra: Coimbra Editora, 2001.

.Direito Constitucional e Teoria da Constituição. $7^{\text {a }}$ ed. Coimbra: Almedina, 1993.

CAPPELLETTI, Mauro. Juizes Legisladores?. Trad. Carlos Alberto Álvaro de Oliveira. Porto Alegre: Sérgio Antônio Fabris Editor, 1999.

CARBONELL, Miguel (Org.). Neoconstitucionalismo(s). Madrid: Editorial Trotta, 2003.

DAHL, Robert A. Sobre a Democracia. Trad. Beatriz Sidou. Brasília: Editora UNB, 2001. DIMOULIS, Dimitri; MARTINS, Leonardo. Teoria Geral dos Direitos Fundamentais. São Paulo: Revista dos Tribunais, 2008. 
FERRAJOLI, Luigi. Garantismo: Uma Discussão sobre Direito e Democracia. Trad. Alexander Araújo de Souza. Rio de Janeiro: Editora Lumen Juris, 2012.

FILHO, Willis Santiago Guerra. Processo Constitucional e Direitos Fundamentais. $5^{\mathrm{a}}$ ed. São Paulo: RCS Editora, 2007.

GRAU, Eros Roberto; CUNHA, Sérgio Sérvulo da.Estudos de Direito Constitucional em Homenagem a José Afonso da Silva. São Paulo: Malheiros, 2003.

HESSE, Konrad. A Força Normativa da Constituição. Trad. Gilmar Ferreira Mendes. Porto Alegre: Sérgio Antônio Fabris Editor, 1991.

KELSEN, Hans. Teoria Pura do Direito. $6^{\text {a }}$ ed. Trad. J. Cretella Jr. e Agnes Cretella. São Paulo: Revista dos Tribunais, 2009.

MONTESQUIEU, Charles Louis de. O Espírito das Leis. Trad. Cristina Muraschco. São Paulo: Martins Fontes, 1993.

QUEIROZ, Cristina M. M. Direito Fundamentais (Teoria Geral). Coimbra: Coimbra Editora. 2002.

REVISTA DEBATES. Porto Alegre, v.7, n. 1, jan.-abr. 2013.

REVISTA DE DIREITO ADMINISTRATIVO. v. 245, 2007. Disponível em: <http://bibliotecadigital.fgv.br/ojs/index.php/rda/article/view/42122/40814>. Acesso em: 18 de fev. de 2017.

REVISTA DE DIREITO ADMINISTRATIVO. v. 250, 2009. Disponível em: <http://bibliotecadigital.fgv.br/ojs/index.php/rda/article/view/4141/2923>. Acesso em: $19 \mathrm{de}$ fev. de 2017.

REVISTA DE DIREITO ADMINISTRATIVO. v. 252, 2009. Disponível em: <http://bibliotecadigital.fgv.br/ojs/index.php/rda/issue/view/560>. Acesso em: $18 \mathrm{de}$ fev. de 2017.

REVISTA DOS TRIBUNAIS. v. 798, 2002.

REVISTA ELETRÔNICA SOBRE A REFORMA DO ESTADO (RERE). Salvador: Instituto de Direito Público da Bahia, n. 2, jun.-ago. 2005. 
REVISTA JURÍDICA. Brasília. v. 10, n. 90, abr.-maio, 2008.

SANTOS, Boaventura de Sousa. Renovar a Teoria Crítica e Reinventar a Emancipação Social. São Paulo: Boitempo, 2007.

SARLET, Ingo Wolfgang; TIMM, Luciano Benetti (Orgs.). Direitos Fundamentais: Orçamento e "Reserva do Possível". 2a ed. Porto Alegre: Livraria do Advogado, 2010.

SILVA. José Afonso da.Aplicabilidade das Normas Constitucionais. $7^{a}$ ed. São Paulo: Malheiros, 2007.

. Curso de Direito Constitucional Positivo. 25a ed. São Paulo: Malheiros, 2005.

SILVA, Virgílio Afonso da.Direitos Fundamentais: Conteúdo Essencial, Restrições e Eficácia. $2^{\text {a }}$ ed. São Paulo: Malheiros, 2010. . (Org.). Interpretação Constitucional. São Paulo: Malheiros, 2007.

[SYN]THESIS: CADERNOS DO CENTRO DE CIÊNCIAS SOCIAIS. Rio de Janeiro: UERJ, v. 5, n. 1, 2012.

TOQUEVILlE, Alexis. A Democracia na América: Leis e Costumes. Trad. Eduardo Brandão. São Paulo: Martins Fontes, 2005. 